\title{
Operationalizing Adolescent Health Services at Primary Health Care Level in India: Processes, Challenges and Outputs
}

\section{Beena Nitin Joshi' ${ }^{1}$, Sanjay Laxman Chauhan², Ragini Nitin Kulkarni' ${ }^{1}$, Babita Kamlapurkar ${ }^{3}$, Rajesh Mehta ${ }^{4}$}

\author{
${ }^{1}$ Department of Operational Research, National Institute for Research in Reproductive Health (ICMR), Mumbai, India \\ ${ }^{2}$ Department of Operational and Clinical Research, National Institute for Research in Reproductive Health (ICMR), \\ Mumbai, India \\ ${ }^{3}$ Health and Family Welfare Bureau, Government of Maharashtra, Pune, India \\ ${ }^{4}$ Child and Adolescent Health WHO SEARO Office, New Delhi, India \\ Email: nirrhdor@yahoo.co.in, slchauhan@hotmail.com,raginik@rediffmail.com,babskamal3@gmail.com,mehtara@who.int
}

How to cite this paper: Joshi, B.N., Chauhan, S.L., Kulkarni, R.N., Kamlapurkar, B. and Mehta, R. (2017) Operationalizing Adolescent Health Services at Primary Health Care Level in India: Processes, Challenges and Outputs. Health, 9, 1-13.

http://dx.doi.org/10.4236/health.2017.91001

Received: November 9, 2016

Accepted: December 27, 2016

Published: December 30, 2016

Copyright (c) 2017 by authors and Scientific Research Publishing Inc. This work is licensed under the Creative Commons Attribution International License (CC BY 4.0).

http://creativecommons.org/licenses/by/4.0/

(c) (†) Open Access

\begin{abstract}
Background: Ministry of Health, Government of India developed the Adolescent Reproductive and Sexual Health (ARSH) strategy and operationalized adolescent health services up to district and sub-district hospital level. Objectives: To operationalize adolescent health services at primary health care level in a block of Maharashtra; assess impact of need based interventions on quality of services; and understand potential for scalability in the state. Methods: Adolescent and Youth friendly centers were established at primary health care settings and interventions such as health system strengthening, sensitizing gatekeepers, involving Accredited Social Health Activist (ASHAs), developing inter and intra-sectoral linkages, improving monitoring and evaluation were tested. Results: Over a period of 2009-2014, there was a steady increase in the number of clients attending the Adolescent and Youth Friendly Health Centers (A\&YFHCs). Attitude of providers to address adolescents' needs improved significantly. Successful interventions were networking with schools, colleges and Non Government Organization (NGOs), linkages with HIV program and Integrated Child Development Services (ICDS), and involvement of ASHAs. Conclusions: The study demonstrates that although health system has the primary responsibility of addressing health issues among adolescents; it has limitations in terms of its reach to adolescents and generating demand for services. There is a need to network with education sector, ICDS, NGOs working for adolescent health and development to work as a team and address the multifaceted needs of the adolescents. Such a strategy will be crucial while implementing the recently launched Rashtriya Kishor Swasthya Karyakram-
\end{abstract}


the new national adolescent health programme in India.

\section{Keywords}

Adolescent Sexual and Reproductive Health, Adolescent and Youth Friendly Health Services, Quality of Care Standards, Linkages

\section{Introduction}

Thirty percent of India's total population comprises of adolescents and youth aged 10 to 24 years [1]. To provide friendly services to the adolescents, the Ministry of Health, Government of India (GOI) launched the Adolescent Reproductive and Sexual Health Strategy [2] in 2005 under the umbrella of National Rural Health Mission (NRHM) as part of Reproductive and Child Health (RCH-II) programme. This strategy intended delivering a comprehensive package of services for adolescent boys and girls including preventive, promotive, curative, counseling and referral services; focusing on sexual and reproductive health by re-organizing the existing public health system and developing linkages between RCH-II and National AIDS Control Program (NACP-III). Implementation Guide [3] outlined the necessary interventions that could make the clinics functional recommending all core domains of adolescent friendly care [4]. A set of tools were developed by World Health Organization (WHO) which used multiple level assessments to validate the quality of each indicator [5]. World Health Organization (WHO) Job aids [6] on adolescent health also ensured uniform management of clinical issues by the trained healthcare providers.

Maharashtra being one of the implementing states, established adolescent health services at District and sub-district hospital settings. However, the district hospital settings lacked community outreach services and manpower to generate demand for services, as their mandate was mainly curative services. Although one post of ARSH counselor was dedicated to this clinic, there were limitations of her/his single handed reach to the community. District hospitals have specialized expertise and their services are utilized for issues that cannot be tackled at the primary health care settings. Since these services were not established below the district level, an implementation research study was undertaken to capacitate the primary health care facilities and test the operational feasibility to provide services to adolescents.

Preliminary work by our institute included working with the district programme managers for developing a district action plan for linked RCH-ARSH and HIV services in the year 2007. In addition to this, tools to assess the service readiness of the public health system, IEC material (posters and pamphlets) in local languages for demand generation and translation of Government of India (GOI's) Auxiliary Nurse Midwifery/Lady Health Visitor (ANM/LHV) training module in Marathi language for capacity building of health care providers to de- 
liver adolescent friendly services were developed and shared with the state government. Financial assistance was received from WHO in the preparatory phase. This work was utilized for planning and implementing the study in Karjat block of Raigad district of Maharashtra. The block had a mix of tribal and non-tribal population and comprised of eight government health facilities viz. one Subdistrict hospital (SDH), one Rural hospital (RH) and six Primary Health Centers (PHCs) located equally in tribal and non-tribal areas each, covering a total population of 2, 17, 363. A quarter of this population belonged to schedule tribes with $60 \%$ literacy. The main occupation was agriculture or petty business. There were no major industries in the block.

This paper pertains to process documentation related to products developed and challenges faced during establishing, strengthening and sustaining the Adolescent Friendly Health Services at sub-district health facilities in the block. The paper also outlines the interventions that worked and those that did not.

\section{Methodology}

This prospective intervention study was conducted from 2009 until 2014 (5 years) with an aim of documenting the process of implementing ARSH services below district level as per the Implementation Guide developed by Government of India. Entire Karjat block of Raigad district was chosen for the study due to operational feasibility and that it had a good representation of tribal and non-tribal populations. All health facilities i.e. six PHCs, one RH and one SDH were included for interventions. The situation analysis included health facility assessment of quality health services provided to the adolescents. Using a check list which identified infrastructure needs along with drugs and consumables, a range of services and quality of care available to adolescents was assessed. Health care providers were interviewed to assess their knowledge on adolescent health issues, training needs and community outreach services provided to adolescents. Needs assessment of the adolescents and youth was done by eight Focus Group Discussions among adolescents and young people aged 10 - 24 years, two each among married and unmarried boys and girls respectively. Quality assessment tools developed by WHO [5] were used to monitor the adolescent friendly health clinics during the study in each phase. Scores were assigned in percentages to the variables specific to each standard. Strategies were implemented to address the shortfalls observed in each assessment.

Based on the findings of the situation analysis (Table 1), interventions categorized into four broad areas were designed namely 1) establishing Adolescent Reproductive and Sexual Health (ARSH) clinics by strengthening health facilities 2) sensitizing community and reaching out to adolescents; 3) strengthening inter- and intra-sectoral linkages and 4) monitoring evaluation and accountability of the health providers.

1) Establishing Adolescent Friendly Health Clinics (A\&YFHCs) by strengthening the existing public health facilities:

Designated adolescent and youth friendly health clinics named "Maitri" 
Table 1. Situation analysis of ARSH services in the block.

\begin{tabular}{|c|c|c|}
\hline $\begin{array}{l}\text { Methodology used to conduct } \\
\text { Situational Analysis }\end{array}$ & Issues Explored & Salient Findings \\
\hline $\begin{array}{l}\text { Focus group discussions (8) with } \\
\text { both males and female married } \\
\text { and unmarried groups-two each }\end{array}$ & $\begin{array}{l}\text { - Major health problems faced by adolescents } \\
\text { - Where do adolescents seek service for their } \\
\text { - } \text { health complaints } \\
\text { Expected services to be available at the } \\
\text { - Acceptth facilities for adolescents } \\
\text { - Convenient day and timing of ARSH clinic } \\
\text { at the health facility }\end{array}$ & $\begin{array}{l}\text { - Menstrual problems, vaginal discharge, mental } \\
\text { stress, problem in conception and RTI/STI were the } \\
\text { common health concerns } \\
\text { - Health seeking behaviour was very poor and they } \\
\text { visited health centers or private practitioners } \\
\text { - They expected to receive sexuality education, } \\
\text { pre-marital counseling, information on HIV/AIDS, } \\
\text { condom, pregnancy care \& contraception at the } \\
\text { public health facilities }\end{array}$ \\
\hline Facility Survey & $\begin{array}{l}\text { - Information regarding available and } \\
\text { sanctioned manpower at the health facility } \\
\text { - Stock of drugs } \\
\text { - Training status of health staff on adolescent } \\
\text { health issues } \\
\text { - Linkage with local bodies (ICDS, local } \\
\text { NGOs or SHGs, Schools, ASHAs) } \\
\text { - IEC material }\end{array}$ & $\begin{array}{l}\text { - Five of the eight health facilities had vacant posts of } \\
\text { either the MO or para-medical staff } \\
\text { - Negligible inter sectoral linkages existed for } \\
\text { adolescent activities } \\
\text { - IEC material specific to adolescent issues } \\
\text { was limited } \\
\text { - Service signage boards did not spell out that they } \\
\text { were available for adolescents }\end{array}$ \\
\hline Interaction with health staff & $\begin{array}{l}\text { - Awareness of ARSH program } \\
\text { - Provision of ARSH services } \\
\text { - Any official guidelines received to } \\
\text { implement ARSH services } \\
\text { - Community level sensitization of } \\
\text { gatekeepers }\end{array}$ & $\begin{array}{l}\text { - Awareness about ARSH program among health care } \\
\text { providers was poor } \\
\text { - A\&YFHCs were not functional at Sub District } \\
\text { Hospital and did not exist at Rural hospital or } \\
\text { any PHCs } \\
\text { - The Medical staff needed guidelines and training } \\
\text { to deal with specific adolescent issues. } \\
\text { - Adolescent girls were being addressed in the } \\
\text { block through ICDS. Health camps, hemoglobin } \\
\text { testing and treatment of iron deficiency anemia } \\
\text { were exiting programs for girls in the block. } \\
\text { - There was no sensitization of the community in } \\
\text { all the areas under these health facilities } \\
\text { concerning SRH needs of the young people, } \\
\text { especially the tribal region. }\end{array}$ \\
\hline
\end{tabular}

(Friendship) were established at all eight health facilities in the block for all adolescents ensuring audio visual privacy. However for the purpose of the study the age group catered included youth as well. The logo and content of the Maitri clinic sign board (Image 1) was finalized in coordination with United Nations Population Fund (UNFPA) and Government of Maharashtra (GOM). Information and education materials on common adolescent health issues along with a self-learning audio visual CD developed by the state government for advocacy with gatekeepers and two CDs on adolescent health education (separate for boys and girls) developed by Marathi Vidynan Parishad were provided to all eight health facilities along with essential medicines to treat common ailments. Schools, anganwadi centers and gram panchayats were also supplied with IEC material. Separate service registers in a particular format were designed to document information on adolescents.

Training of sixteen Medical Officers was conducted using the RCH-II ARSH 


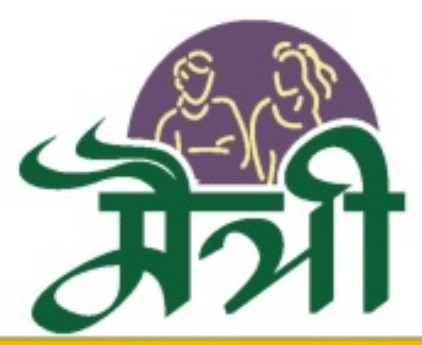

किशोरांसाठी संवाद आणि सेवा केंद्र

- माहिती (शारिरीक व मानसिक आरोग्य)

- समुपदेशन / सल्ला

- विवाहपूर्व मार्गदर्शन

कुट्रुंब नियोजन साधने

वैद्यकीय तपासणी व उपचार

वेळ: दर सोमवारी दुपारी २ ते ४

Image 1. Sign board of Adolescent Health Services in local language of the study site (Marathi).

training modules [6] and WHO Adolescent Job aid [7]. One hundred and eleven Paramedical staff, three hundred and nineteen Anganwadi Workers, one hundred and forty three ASHA workers were also trained in several batches. Preand post-training assessments were followed by refresher trainings and feedback regarding difficulties faced on job. The facilities were inaugurated during 20092010 by prominent local politicians in presence of local adolescents, youth, teachers and parents. Rallies, street plays on various adolescent health topics along with mass health checkup camps marked these events.

\section{2) Sensitizing gatekeepers and reaching out to adolescents.}

A local committee was set up for the A\&YFHCs with representatives from local self-government, health care providers, a paramedical staff adolescents ( 1 boy and 1 girl), school teacher and legal representative, if available to get community support for the ARSH activities. To create adolescent friendly environment in the community multiple group meetings were conducted with gatekeepers, mainly the Panchayat members (200 members of 50 panchayats including Sarpanches), 135 School teachers and parents of adolescents. Adolescent health education programs were undertaken for married and unmarried adolescents in the community either through schools and ICDS workers.

3) Developing inter- and intra-sectoral linkages (Table 2):

The study also attempted to link ARSH services with the existing HIV (Human Immuno Deficiency Virus) services. Official permissions were obtained to permit counselor and lab technician of Sub-district and rural hospital to assist in providing ARSH services at PHC level.

Linkages were developed between A\&YFHCs, school health services and NGOs. ANMs accompanied the school health team during school health checkups to conduct awareness program and identify cases that were referred to Adolescent Friendly Health Centers (A\&YFHC). Standard Operating procedures were developed to establish these linkages. The existing WIFS (Weekly Iron and 
Folic Acid Supplementation) program at school level was also linked with the ARSH services and teachers were encouraged to refer any students who were non-compliant or reported any health problems. Trained ASHAs were paid cash incentive of Rs. 10/- for every referred case to the clinic or during camps in the last phase of the project in consultation with the state government.

Peer volunteers were selected from the NSS cadets at different colleges as well as from the community. They were sensitized and were given an agenda to advocate adolescent issues in their respective villages and refer clients to the $A \&$ YFHCs.

\section{4) Monitoring and Evaluation:}

Quarterly meetings with the state, district and block officials for health, Integrated Child Development Services (ICDS) and Education departments were held to review the progress. For each health facility progress towards achieving the targets were discussed and challenges faced and problems solved were presented. This exercise helped to identify problems and plan corrective interventions. Assessment of quality of services against the seven standards as laid down in the ARSH Implementation Guide were carried out every year at each A\&YFHC using Quality Assessment tools developed by WHO.

\section{Results}

Training health care providers led to significant improvements in their knowledge, attitude on adolescent problems and their approach of dealing them (Table 3). Issues like contraception to be provided to unmarried adolescents or counseling on masturbation were challenging issues to convince providers mainly the grass root functionaries as it questioned their own beliefs and social norms. The community based activities enabled creation of an adolescent friendly environment leading to increased attendance of adolescents at the A\&YFHCs. MIS helped to record age and sex disaggregated information on adolescent-specific problems.

Quarterly intersectoral meetings encouraged good practices and sensitive issues dealt in adolescent friendly manner were discussed. Problems that needed intervention by the district and state level officials were identified and actions were taken to pursue the same with respective departments. Based on the flow of clients to the clinic, the once a week clinic was modified to any day clinic ensuring adequate time was given to the adolescent clients. Providers were encouraged to allow anonymous registration if adolescents so demanded to facilitate adolescents access services providing privacy. Providers had constraints to tackle unmarried pregnancies and provide contraceptives to unmarried girls. They were repeatedly asked to refer to the implementation guide which provided guidance regarding ARSH services to adolescents.

Involving Peer Volunteers, NSS groups and Adolescent health committee had limited scope for reasons mentioned in Table 2. Their roles and responsibilities need to be more clearly defined. The total number of cases referred by ASHAs during the study period was 828. A number of coordinated activities were ar- 
Table 2. Interventions to facilitate intra and inter-sectoral linkages and its outcome.

\begin{tabular}{|c|c|c|}
\hline Linkages & Type of Intervention & Outcome of Interventions \\
\hline $\begin{array}{l}\text { 1. Linkages with School health } \\
\text { services }\end{array}$ & $\begin{array}{l}\text { - The annual school health check-up was done in the } \\
\text { presence of paramedical staff of the nearby PHC. } \\
\text { IEC material was displayed during this activity and } \\
\text { awareness talks were organized. } \\
\text { - Any adolescent who needed intervention was re- } \\
\text { ferred to the PHC staff present in the school for fur- } \\
\text { ther follow up and intervention as may be } \\
\text { required. } \\
\text { - Thus schools were linked to the A\&YFHCs } \\
\text { - Schools teachers/Principals/Kendra Pramukhs were } \\
\text { sensitized to adolescent health needs and how to } \\
\text { address adolescent health problems. } \\
\text { - Self-learning VCDs were made available in all } \\
\text { secondary schools to help teachers conduct } \\
\text { adolescent health education in a more effective way. }\end{array}$ & $\begin{array}{l}\text { An interface between A\&YFHC and } \\
\text { school health services has been } \\
\text { developed. } \\
\text { - Adolescent friendly environment } \\
\text { created at the schools } \\
\text { Education department has agreed on } \\
\text { inclusion of ARSH program activities } \\
\text { in their regular schedule in schools. } \\
\text { - Health education activities followed by } \\
\text { question-answer sessions, } \\
\text { essay/debate/ speech competitions } \\
\text { are being conducted in schools. }\end{array}$ \\
\hline 2. Linkages with ICTC Centers & $\begin{array}{l}\text { - Integrated Testing and Counseling Centers (ICTC) } \\
\text { counselors and technicians were trained and } \\
\text { involved in ARSH program activities to bring about } \\
\text { convergence in the block so that adolescents receive } \\
\text { both the services under one roof. } \\
\text { - Directive from District AIDS unit(DAPCU) has } \\
\text { been sent to the ICTC centers for their involvement } \\
\text { in the program. }\end{array}$ & $\begin{array}{l}\text { - Linked ARSH and HIV services } \\
\text { provided } \\
\text { ICTC counselors and technicians } \\
\text { visit PHCs ( } 3 \text { each) on fixed days to } \\
\text { provide counseling service not only } \\
\text { related to HIV/AIDS but also on } \\
\text { ARSH. }\end{array}$ \\
\hline $\begin{array}{l}\text { 3. Linkages with } \\
\text { Non-Government Organizations } \\
\text { (NGOs) }\end{array}$ & $\begin{array}{l}\text { - Local NGOs actively working in the block with } \\
\text { common goals were identified and a link between } \\
\text { them and A\&YFHC was established. } \\
\text { - Joint activities with A\&YFHC were planned and } \\
\text { undertaken in the community to create awareness } \\
\text { and generate demand for services. }\end{array}$ & $\begin{array}{l}\text { Local NGOs have a strong hold in the } \\
\text { community. Their involvement and } \\
\text { linkage with the health facilities has } \\
\text { boosted an enabling environment for } \\
\text { adolescent health in the community. }\end{array}$ \\
\hline $\begin{array}{l}\text { 4. Linkages with Integrated Child } \\
\text { Development Scheme (ICDS) and } \\
\text { ASHAs }\end{array}$ & $\begin{array}{l}\text { - Anganwadi workers, supervisors and ASHAs were } \\
\text { trained on ARSH. } \\
\text { - They provided services to adolescents on VHND } \\
\text { days and referred them to the PHCs if required. } \\
\text { ASHA received incentive of Rs. 10/-per referral of } \\
\text { adolescent client to the A\&YFHC for ARSH related } \\
\text { complaint was piloted through the project. }\end{array}$ & $\begin{array}{l}\text { ASHA's were found to have huge } \\
\text { potential as a link between adolescents } \\
\text { in the community and service } \\
\text { providers. } \\
\text { Mobilizing adolescents to seek services } \\
\text { especially during outreach activities } \\
\text { were well taken care by them. } \\
\text { - Overall } 828 \text { referrals were made by } \\
\text { ASHAs during last three years of the } \\
\text { project period. } \\
\text { Oral/accompanied referral is followed } \\
\text { in the block by ASHAs, aganwadi } \\
\text { workers and ANMs. }\end{array}$ \\
\hline $\begin{array}{l}\text { 5. Linkages with Peer } \\
\text { Volunteers/National } \\
\text { Service Scheme (NSS) }\end{array}$ & $\begin{array}{l}\text { - Identification and training of Peer Volunteers by } \\
\text { block health officials as per state government } \\
\text { guidelines. } \\
\text { - Involvement of NSS volunteers in demand } \\
\text { generation activities }\end{array}$ & $\begin{array}{l}\text { Outcome was not very successful due } \\
\text { to unclear roles and responsibilities. } \\
\text { Investment in training NSS students } \\
\text { was not productive due to frequent } \\
\text { turnover of trained students each year }\end{array}$ \\
\hline
\end{tabular}

ranged due to networking with education institutes, NGOs and other sectors that improved linkages and referrals. 
Table 3. Improvement in knowledge about ARSH issues among paramedical staff post training ie after 3 days (correct response) $\mathrm{n}=133$.

\begin{tabular}{ccc}
\hline Adolescent health Issues & $\begin{array}{c}\text { PRE-TEST } \\
\text { mean (\%) }\end{array}$ & $\begin{array}{c}\text { POST-TEST } \\
\text { mean (\%) }\end{array}$ \\
\hline Adolescent growth and development & 44 & 56 \\
Communication with the adolescent & 41.7 & 58.3 \\
Adolescent friendly health services & 41.9 & 58.1 \\
Sexual \& Reproductive health services & 47.3 & 52.7 \\
Nutrition \& anemia in adolescent & 45.8 & 54.2 \\
Pregnancy \& Unsafe abortion & 48.4 & 51.6 \\
Contraception for adolescents & 49.7 & 50.3 \\
\hline
\end{tabular}

Quality Assessment reflected an increased overall composite score for all seven standards from 28 at baseline to 81 at the end of four years signifying that the standards for adolescent friendliness were achieved.

There was a steady increase in the attendance of girls and boys seeking preventive and curative services for a number of reproductive health issues (Table 4). These belonged to mainly rural and tribal areas both school and non-school going. The MIS of the health system does not capture details of the socio-demographic characteristics. However they were all local residents availing services. Seeking answers on adolescent growing-up issues was the most common reason to approach Adolescent Friendly Health Centers (A\&YFHC) along with menstrual problems among girls, nutrition related issues, reproductive tract infections and skin disorders. They were also offered immunization (booster dose DT at 10 years) and screening for sickle cell anemia mainly at the tribal health centers. Among the $10-19$ year old clients, approximately $80 \%$ of adolescents were unmarried and this was exactly opposite among the 20 - 24 year olds where majority of girls were married.

\section{Contribution to State-Wide Scaling up of A\&YFHCs}

Process and products developed over the project period were handed over to the officials of the government of Maharashtra for possible adaptation for the state programme. Design and content of the sign board for the A\&YFHC-the "Maitri" Clinic has been subsequently used for all A\&YFHCs in the state government programme and has helped recognition and branding of these clinics. Government of India's ANM training package was translated in local language Marathi for the project and has been used for state-wide trainings. Adolescent-specific IEC materials developed during the pre-project phase were transformed into five posters and three pamphlets by the state government (Image 2). Standard Operating procedures to establish the linkages between A\&YFHCs and School Health Services were shared with the state government. The project investigators at our institute were nominated on the Task Force Committee of the Government of 
Table 4. Presenting complaints by 23,570 adolescents and young people during utilization of services.

\begin{tabular}{|c|c|c|c|c|}
\hline \multicolumn{5}{|c|}{ (April 2010-March 2014) } \\
\hline \multirow{3}{*}{ Problems } & \multicolumn{2}{|c|}{$10-19$ yrs. } & \multicolumn{2}{|c|}{$20-24$ yrs. } \\
\hline & \multicolumn{2}{|c|}{ 2011-2014 } & \multicolumn{2}{|c|}{ 2011-2014 } \\
\hline & Male & Female & Male & Female \\
\hline Menstrual problems & 0 & 1896 & 0 & 823 \\
\hline ANC (Antenatal Care) & 0 & 560 & 0 & 6283 \\
\hline PNC (Post natal Care) & 0 & 5 & 0 & 14 \\
\hline Skin problems & 535 & 677 & 108 & 101 \\
\hline $\begin{array}{c}\text { RTI/STI (Reproductive } \\
\text { Tract Infections and } \\
\text { Sexually Transmitted } \\
\text { Infections) }\end{array}$ & 110 & 248 & 38 & 198 \\
\hline Nutritional disorders ${ }^{\star}$ & 534 & 2790 & 216 & 875 \\
\hline Growing up concerns ${ }^{* *}$ & 676 & 1522 & 80 & 142 \\
\hline Immunization & 529 & 374 & 41 & 20 \\
\hline Counseling & 272 & 415 & 78 & 131 \\
\hline $\begin{array}{l}\text { Family planning } \\
\text { acceptors }\end{array}$ & 0 & 2 & 19 & 281 \\
\hline MTP & 0 & 3 & 0 & 81 \\
\hline Screening for Sickle cell & 212 & 337 & 35 & 102 \\
\hline HIV/AIDS & 2 & 5 & 24 & 12 \\
\hline Others & 317 & 233 & 21 & 30 \\
\hline
\end{tabular}

${ }^{*}$ Nutritional concerns-Anemia, underweight, Vitamin deficiency etc. ${ }^{*}$ Growing up Concerns such as height weight, body image, breast development, sexual attraction, acne, masturbation etc.

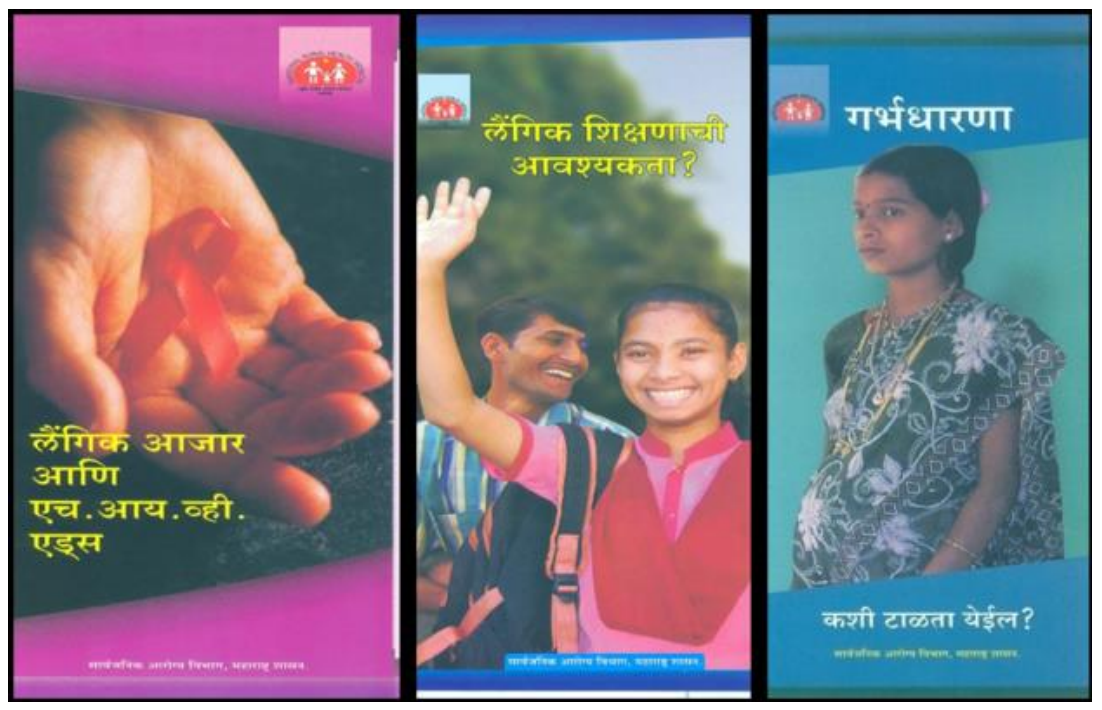

Image 2. Information Education material on adolescent reproductive health issues in local language of the study site (Marathi).

Maharashtra to provide technical assistance in rolling out the adolescent health 
programme in the State. At the end of the project, the eight A\&YFHCs have been sustained through the budget provision made by the state health department in their annual program implementation plan.

\section{Discussion}

This study in collaboration with Government of Maharashtra was piloted to test integration of adolescent friendly health services within the public health system at primary health care level in a block at a time when ARSH services in the state of Maharashtra were available only up to the district and sub district hospital level.

The study succeeded in identifying the strengths and weakness of health system as to what interventions can health system undertake on its own and which interventions need collaboration and linkages with other programmes and institutions. Successful interventions were: Community activities to create enabling environment for adolescent health; strengthening of existing health facilities to develop A\&YFHCs based on the Implementation Guide for Adolescent Reproductive and Sexual Health; involvement of ASHAs for mobilizing adolescent clients in the community by providing incentives; establishing linkages of the A\&YFHCs with school health services; integration with HIV services; and networking with local NGOs. Attendance by adolescents in the A\&YFHCs progressively improved over time presenting with a broad range of problems to very sensitive and private issues like sexual health. We observed that special efforts are needed to attract male clients to these A\&YFHCs through targeted outreach activities. SOPs for establishing linkages between several existing services and different programs were found effective and shared with the State and district officials. Creating an enabling environment in the community facilitated improved utilization of services satisfying the key indicator of quality of care [8].

The study found that it is challenging for the overburdened health system to single handedly manage all dimensions of interventions that are necessary to implement the national Adolescent Reproductive and Sexual Health strategy. Innovative approaches like Youth Information Centers [9] have been reported in literature to conduct outreach activities that help mobilize adolescent clients. Improved awareness and health seeking behavior of adolescents following outreach activities have also been reported [10]. Having multiple actors but no ownership or accountability of health parameters by various stake holders has led to the poor response of ARSH program in India [11]. This could be best accomplished by fostering intra and intersectoral linkages. A study comparing two models of adolescent service delivery found utilization of school health services better than dispensary based health clinics and adolescents reported more of psychological and behavioural problems [12]. However, these models are difficult to replicate and sustain as they involve a full time dedicated health staff at every school. So a more feasible model could belinking these two services, as has been recommended by our earlier study [13]. It is important for school health services to include sexual and reproductive health education along with school 
health checkups inclusive of reproductive health with good referral linkage to A\&YFHC.

Most programs for adolescents evaluate the clinic service uptake. This seems to be a poor indicator especially when the services are rolled out at the community level with involvement of sub-centers and PHCs. Most adolescents are a healthy group and do not have many health problems. We cannot expect huge numbers crowding our Out Patient Departments. Through outreach programs preventive and promotive services are provided which in itself is an important service component. Equipping them with appropriate information to reduce risky behaviour and promoting healthy lifestyle remains the major element of the outreach program. The issues addressed in these activities and change in knowledge and attitudes of these young people after attending these activities are unaccounted for in the routine MIS.

The data from few intervention studies published earlier illustrate that adolescents typically seek multiple services at any one visit, with counselling being the most popular service, followed by medical examination [14]. Each client receives separate services but is treated as a single client thus reflecting limited attendance at the health facility. Boys and girls reported similar problems as that from urban areas [15]. For a broad based programme, it is important to measure impact of these interventions on key indicators such as age at marriage, age at first birth, ANC and reduction in maternal and infant morbidities and mortalities along with reduction in incidence of sexually transmitted infections. However, this was the limitation of the study due to its short period of observation which helped measure only output and not these important outcomes. Monitoring the impact of ARSH program is difficult through routine HMIS, as age segregated data on indicators of maternal health; RTI/STI and contraception are not available.

With the increased urbanization and delay in age of marriage the young people beyond 19 years also form a vulnerable group. Hence expanding the agegroup of adolescents from 10 - 19 to 10 - 24 years could help bring a larger population under the program as seen in the study. Policy issues regarding imparting sexuality education in schools, anonymous registration, issues of privacy and confidentiality, tackling of unmarried pregnancy, providing contraceptives to unmarried girls etc. should be clarified further so that such services could be delivered effectively to adolescents.

Our study has revealed that the health system found it challenging to generate demand for ARSH services supported by good quality of care. Chandra, Lane and Wong have recommended that implementers should adopt only the best practices from evidence that already exists and avoid strategies (eg. Peer education) which have not worked in the field of ARSH [16]. With the introduction of a broader agenda of Rashtriya Kishor Swasthya Karyakram [17] that covers many other aspects of adolescent health and behaviours, health systemhas to respond to many other components of adolescent health beyond ARSH to achieve the targets of this ambitious program. While RKSK has its own advantage of be- 
ing very holistic, the skills of the providers for improved coordination to roll out this program become extremely crucial.

Collaboration and networking are key strategies to improve adolescents' access to services supported by a favorable adolescent friendly atmosphere both in the community as well as health facility by trained sensitive providers. Regular monitoring of activities and maintaining records in the form of MIS is crucial to identify gaps and introduce strategies to address them. Refresher training of health providers is very essential to address their concerns when they start providing adolescent services. The research agency facilitated testing strategies to strengthen the health system to address the adolescent sexual and reproductive health issues and documenting the outcomes. There is a need to network with organized and unorganized sectors such as education, ICDS, NGOs working in the field of adolescent health and development to work as a team and address the multifaceted needs of the adolescents. Such a strategy will be crucial while implementing the recently launched Rashtriya Kishor Swasthya Karyakaram (RKSK) the new national adolescent health programme in India.

\section{Acknowledgements}

We wish to acknowledge the financial support received from World Health Organization (WHO) for first year and Government of Maharashtra for three consecutive years. We duly acknowledge the technical support provided by Dr. Neena Raina and Dr. Arvind Mathur at World Health Organization (WHO) South East Asia Regional Office (SEARO), New Delhi and the administrative support provided by all the Additional Directors' I/C of adolescent health in the state government and their offices during the study period namely Dr. Ashok Chitale, Dr. Smita Ganu. We also wish to acknowledge the support leant by District health authorities Raigad and the Taluka Health Officers' and their staff for facilitating conduct of the research study. Integrated Child Development Services(ICDS),District AIDS Prevention Control Unit (DAPCU) and School health officials in the block deserve a special mention. The entire cadre of health providers from Medical Officers to Accredited Social Health Activists (ASHA) were part of the team who actually implemented the work at ground zero. The independent team of researchers who facilitated conduct of the quality assessment also deserve a special mention. Non-Government Organization (NGOs) and a number of other support persons and organizations who contributed in their respective capacities during the conduct of various activities are also acknowledged. We acknowledge the CDs (documentaries) on sexuality education developed and shared by Marathi Vigyan Parishad, Mumbai and the school and college teachers and students who participated in training sessions and organized students' awareness programs. We also thank the Director and the research team from NIRRH and all the adolescents who supported in this activity.

\section{References}

[1] Census (2011) Government of India. http://censusindia.gov.in 
[2] ARSH Strategy Government of India (2004).

[3] Implementation Guide National Rural Health Mission (2006) Implementation Guide on RCH II Adolescent Reproductive Sexual Health Strategy for State and District Programme Managers.

http://www.searo.who.int/entity/child_adolescent/topics/adolescent_health/rch_asr h_india.pdf

[4] Ambresin, A.E., Bennett, K., Patton, G.C., Sanci, L. and Sawyer, S.M. (2013) Assessment of Youth-Friendly Health Care: A Systematic Review of Indicators Drawn from Young People's Perspectives. Journal of Adolescent Health, 52, 670-681.

[5] Quality Assessment Guidebook (2009) A Guide to Assessing Health Services for Adolescent Clients. WHO.

[6] Adolescent Job Aid World Health Organization (2010) WHO Production Services, Geneva.

[7] ARSH Training Modules Orientation Programme for MOS, ANMs/LHVs to Provide Adolescent Friendly Reproductive and Sexual Health Services Govt of India.

[8] Mehra, S., Sogarwal, R., Nair, V., Mahasweta, S., Tiwari, R. and Dwivedi, K. (2013) Determinants of Youth Friendly Services Influencing Client Satisfaction: A Study of Client's Perspectives in India. Indian Journal of Public Health Research \& Development, 4, 221-226.

[9] Yadav, R.J., Mehta, R., Pandey, A. and Adhikari, T. (2009) Evaluation of Adolescent-Friendly Health Services in India. Health and Population Perspectives, 32, 6672.

[10] Sogarwal, R., Chandra, M. and Mehra, S. (2013) Youth Friendly Health Services and Role of Outreach Activities to Improve Access to Services. Open Journal of Preventive Medicine, 3, 191-198.

[11] Gupta, M., Ramani, K.V. and Werner, S. (2012) Adolescent Health in India: Still at Crossroads. Advances in Applied Sociology, 2, 320-324. https://doi.org/10.4236/aasoci.2012.24042

[12] Kumar, R., Prinja, S. and Lakshmi, P.V.M. (2008) Health Care Seeking Behavior of Adolescents: Comparative Study of Two Service Delivery Models. The Indian Journal of Pediatrics, 75, 895-899. https://doi.org/10.1007/s12098-008-0098-2

[13] Joshi, B., Chauhan, S., Bhadoria, V., Varsha, T. and Neelawanti, G. (2006) Reproductive Health Problems and Help Seeking Behaviour among Adolescents in Urban India. Indian Journal of Pediatrics, 73, 509-513.

[14] Mehra, S., Sogarwal, R. and Chandra, M. (2013) Integrating Adolescent-Friendly Health Services into the Public Health System: An Experience from Rural India. WHO South-East Asia Journal of Public Health, 2, 165-173.

[15] Joshi, B., Chauhan, S., Ghule, M. and Kulkarni, R. (2009) Developing Service Delivery Models for Providing Adolescent Reproductive and Sexual Health Services: NIRRH Experiences. In: Ashwini, B.-G. and Parag, B., Eds., Gynecological Manual on Adolescent Girls and Young Women, FOGSI Publication, Jaypee Publishers, New Delhi, 401-421.

[16] Chandra, M.V., Lane, C. and Wong, S. (2015) What Does Not Work in Adolescent Sexual and Reproductive Health: A Review of Evidence on Interventions Commonly Accepted as Best Practices. Global Health: Science and Practice, 3, 333-340. https://doi.org/10.9745/GHSP-D-15-00126

[17] Karyakram, R.K.S. (2014) Operational Framework, Translating Strategies into Programs. Adolescent Health Division, Ministry of Health and Family Welfare, Government of India. 
Submit or recommend next manuscript to SCIRP and we will provide best service for you:

Accepting pre-submission inquiries through Email, Facebook, LinkedIn, Twitter, etc. A wide selection of journals (inclusive of 9 subjects, more than 200 journals)

Providing 24-hour high-quality service

User-friendly online submission system

Fair and swift peer-review system

Efficient typesetting and proofreading procedure

Display of the result of downloads and visits, as well as the number of cited articles Maximum dissemination of your research work

Submit your manuscript at: http://papersubmission.scirp.org/

Or contact health@scirp.org 